\title{
Służba ideologii i ideologia służby w pamiętnikach działaczy polskiego ruchu narodowego na Śląsku Cieszyńskim sprzed końca I wojny światowej
}

\begin{abstract}
In her article, Katarzyna Szkaradnik analyses the memoirs of the pioneers of the Polish national movement in the area of Cieszyn Silesia, and also the memoirs of subsequent social, cultural, and educational activists written before the end of World War I. Szkaradnik examines these texts by focusing on the representations of the idea which the authors were spokesmen for, i.e., Polishness as a cultural legacy as well as Poland as a promised land where the people of Cieszyn Silesia will gain due rights. The metaphors "awakening" and "rebirth" naturalized the bond between these people and Polishness, which was supposed to last thanks to, among other things, Polish religious publications, despite Silesia's separation from so-called Motherland. In this respect, the memoirs have persuasive-didactic functions in that they help to build and strengthen the national identity. Szkaradnik examines the rhetorical strategies used by the activists (and scholars) of the said movement as well as the system of values which they propagate. The fact of the national activists' being servants of an ideology is accompanied by their ideology of service, akin to the positivist idea of educational and economic work. Importantly, most of the authors descended from local people of humble origin and they gave up on the chance of social advancement in order to help their countrymates to attain social, political, and intellectual emancipation.
\end{abstract}

Key words: Polish national activists, national identity, memoirs, Cieszyn Silesia, ideology 
„Takeśmy marzyli, zapaleńcy młodzi, przy wstępie do życia w służbie ojczystej ziemi” (Kubisz, 1928, s. 227).

\section{Wprowadzenie}

Interesującą egzemplifikację konstruowania tożsamości politycznej — a zarazem ideologicznego potencjału literatury dokumentu osobistego ${ }^{1}$ - stanowią wspomnienia pionierów polskiego ruchu narodowego i późniejszych polskich działaczy kulturalno-oświatowych na Śląsku Cieszyńskim². Trzeba zaznaczyć, że liczba tego rodzaju polskojęzycznych tekstów wyróżnia ów obszar nawet na tle Górnego i Dolnego Śląska, czego przyczyn można szukać w zasięgu oświaty ludowej’, a także w innej strukturze społeczno-ekonomicznej i etnicznej oraz w odmiennych warunkach politycznych w monarchii habsburskiej niż pod panowaniem pruskim. Notabene autorzy analizowanych dalej utworów nierzadko operowali pojęciami „Śląsk”, „Ślązak” itp., choć mieli na myśli jedynie część regionu leżącą na terenie Austrii (potem Austro-Węgier), toteż ich poglądów czy stwierdzeń - oraz płynących z nich analiz - nie należy rozciągać na historyczny Śląsk sensu largo.

Rzecz jasna, w rywalizacji o „rząd dusz” różne stronnictwa posługiwały się głównie publicystyką, niemniej memuary także spełniały funkcje agitacyjno-dydaktyczne, służąc konstytuowaniu wspólnoty wyobrażonej. Inaczej niż autobiograf, piszący pamiętnik jest zorientowany na świat zewnętrzny; przeważnie osadza własny życiorys na szerszym tle historycznym i społecznym, jednak owe realia

${ }^{1}$ Przyjmuję tu definicję ideologii jako „względnie usystematyzowanego zbioru poglądów jakiejś grupy społecznej, których funkcją jest orientowanie zbiorowego działania” (Sajko, red., 1996, s. 333).

${ }^{2}$ Listę kilkunastu pamiętników inteligencji polskiej chłopskiego pochodzenia z Cieszyńskiego można znaleźć w szkicu Brody (1997, s. 91-92). Zgodnie z tytułem artykułu przyjmuję tu jako cezurę koniec I wojny światowej, gdyż pamiętniki działaczy polskich opisujące konflikt wokół przynależności regionu po I wojnie światowej (najazd czeski w 1919 roku, odgórny podział Śląska Cieszyńskiego, aneksja tzw. Zaolzia przez Rzeczpospolitą w 1938 roku) mają odmienną dominantę, będącą reakcją na te burzliwe wydarzenia (zob. np. Szkaradnik, 2016, s. 55-69).

${ }^{3}$ Upowszechnieniem oświaty można tłumaczyć pojawianie się między cieszyńskimi włościanami już od XVIII wieku posiadaczy biblioteczek i autorów zapiśników (protopamiętników), swoistych silva rerum (zob. np. Broda, 1978, s. 58-90). Zwracając uwagę na wyjątkowość fenomenu „piśmiorzy”, badacze wskazują na kult słowa drukowanego wśród miejscowych ewangelików w środowisku wiejskim i na związek początków ludowego piśmiennictwa na Śląsku Cieszyńskiem z tym wyznaniem. W przechodzących z pokolenia na pokolenie księgach religijnych odnotowywano informacje biograficzne, a owe notatki z biegiem lat rozrastały się i usamodzielniały. „W zapiśnikach dominują teksty religijne oraz »egzystencjalne«, czyli odnoszące się do najważniejszych spraw ludzkiego życia, jak je mogli rozumieć mieszkańcy cieszyńskiej wsi w XIX stuleciu. Nie brakuje jednak fragmentów odnoszących się [...] do przeszłości, przy czym są to niemal wyłącznie teksty mówiące o Kościele ewangelickim. Dla chłopów historia jako taka nie była oddzielona od spraw religii, [...] ale też stanowiła element tego, co mogło się przydać w życiu codziennym” (Spyra, 2015, s. 277). 
interpretuje (mniej lub bardziej wprost) z określonej perspektywy ideologicznej. Wykorzystuje rozmaite środki stylistyczno-retoryczne, by oddziaływać na emocje, a perswazyjności jego tekstu sprzyja — przynależny mu z definicji gatunku — status osobistego świadectwa, „zeznań” uczestnika wydarzeń. Dzięki temu memuary krzewicieli świadomości narodowej stawały się kartą przetargową w negocjacjach o uznanie polskiej tożsamości (zob. Kubica, 2011, s. 40).

$\mathrm{W}$ rozpatrywanych tu pamiętnikach naświetlę dwa aspekty. Po pierwsze, reprezentacje idei, której rzecznikami byli piszący, czyli gloryfikowanego „czucia polskiego" i polskiego języka - w reprezentacjach tych przejawia się tytułowa „służba ideologii”. Po drugie, propagowany przez autorów system aksjonormatywny, czyli swoiście pojętą „,ideologię służby”, nad której specyfiką i rozumieniem szczególnie pragnę się zastanowić.

\section{Przez polszczyznę do polskości}

Na wyłonienie się w okresie Wiosny Ludów i rozprzestrzenianie polskiego ruchu narodowego na Śląsku Cieszyńskim wpłynęło szereg czynników. Wśród tych z odleglejszej przeszłości warto wymienić choćby obowiązkowe nauczanie szkolne w epoce reformacji w języku używanym przez lud, a także popularność m.in. Biblii gdańskiej oraz Postylli chrześcijańskiej ks. Samuela Dambrowskiego wśród licznych miejscowych ewangelików (zob. np. Sosna, 2015, s. 26). Kardynalne znaczenie miał poziom ekonomicznego i społecznego rozwoju regionu, czyli zarówno procesy modernizacyjne idące $\mathrm{w}$ parze $\mathrm{z}$ industrializacją (prężny ośrodek przemysłu metalowego w Zagłębiu Ostrawsko-Karwińskim), jak i wspomniane już rozpowszechnienie oświaty.

Bezpośrednim bodźcem dla tzw. pierwszych szermierzy sprawy polskiej okazała się konieczność szlifowania własnej polszczyzny przed objęciem posady nauczyciela lub księdza; przykład dali im czescy koledzy z Gimnazjum Ewangelickiego w Cieszynie, którzy zawiązali kółko (Česká Beseda) w celu samokształcenia w języku ojczystym (zob. np. Buława, 1992, s. 13). Symboliczną oznakę skrystalizowania się omawianego ruchu stanowił protest reprezentantów Śląska Cieszyńskiego na Zjeździe Słowiańskim w Pradze w 1848 roku przeciw wcieleniu ich do sekcji czesko-słowackiej. Z kolei za najistotniejszy motyw polityczny inicjatorów tego ruchu uznaje się

równouprawnienie językowe ludności polskiej w życiu publicznym. Środkami jego realizacji były podejmowane próby wprowadzania własnych przedstawicieli do regionalnych i ogólnopaństwowych ciał ustawodawczych. Celem nadrzędnym było budzenie [sic!] polskiej świadomości narodowej wśród polskojęzycznych rodaków i ich językowo-polityczna wewnętrzna suwerenność w ramach Austrii. Powstało ideologiczne pojęcie polskiego narodowego stanu posiadania, 
które obejmowało większą część Śląska Cieszyńskiego [...] (Gruchała, Nowak, 2013, s. 162) .

Kwestia pozycji języka jawi się jako fundamentalna, ponieważ szanse na awans społeczny gwarantował wyłącznie akces do kultury niemieckiej. W rezultacie tak nabytego kompleksu niższości część autochtonów polskiego pochodzenia, która zdobyła pewne wykształcenie i majątek, zaczęła się wstydzić nawet pierwotnego imienia (zob. np. K. Kotula, 1998, s. 67). Jeszcze przybyły w 1898 roku na Śląsk Cieszyński Michał Janik podkreśla, iż on i inni nauczyciele gimnazjum polskiego starali się wszędzie mówić po polsku, wśród ludu bowiem panowała opinia, że z „naszóm rzeczóm” (czyli lokalną odmianą polszczyzny) daleko się nie zajdzie (Janik, 1929, s. 30).

Jak już zostało zasygnalizowane, na skutek nauki w niemieckich gimnazjach także prekursorzy polskiej idei narodowej w Cieszyńskiem sukcesywnie tracili biegłość w „domowym” języku. O uzmysławianiu sobie owych niedostatków świadczy tytuł pamiętnika Andrzeja Kotuli, jednego z owych pionierów: Szkoła polszczyzny. Dziennik poświęcony ćwiczeniu się w języku macierzystym. Podobnemu celowi służyły stowarzyszenia. Paweł Stalmach w 1842 roku powołał do istnienia $\mathrm{w}$ gimnazjum ewangelickim Złączenie Polskie, a pięć lat później wraz z Andrzejem Cinciałą odbył słynną pieszą wyprawę do Krakowa po polskie książki. Drugi z wymienionych założył w 1847 roku Towarzystwo Uczących się Języka Polskiego, którego członkowie zbierali podania ludowe oraz szkolili się w wygłaszaniu przemówień. Ksiądz ewangelicki Jan Pindór wspomina:

My, dzieci polskie, czułyśmy się dlatego w mieście i szkole zupełnie obcymi [...]. Żal nam było naszego macierzyńskiego języka, który na korzyść języka niemieckiego wszędzie usuwany był na bok. Aby go nie zapomnieć i znajomość jego pogłębić, zawiązaliśmy między sobą związek [...]. Ożywione zostały te pragnienia przez przyjście ks. dr. [Leopolda - K.S.] Otto do Cieszyna. Koło niego zaczęła się natychmiast skupiać polska młodzież gimnazjalna, przejmowała się jego ideałami, zajmowała się sprawami narodu polskiego, kształciła się w języku polskim, którym ks. Otto przepięknie władał (Pindór, 1932, s. 46).

W tym wypadku impuls pochodził od proboszcza cieszyńskiego przybyłego z Warszawy, lecz z relacji ks. Pindóra wynika, że młodzież zjeżdżająca do miasta z okolicznych wiosek sama czuła dyskomfort z racji hegemonii niemczyzny i potrzebowała tylko zachęty do działania. Na ogół jednak wyglądało to inaczej, co uwypukla twórca Pamiętnika Czytelni Ludowej w Cieszynie (1887) wydanego na 25-lecie owej instytucji. Wypomina on tygodnikowi „Gwiazdka Cieszyńska”, iż „Jana Śliwkę, zasłużonego autora polskich książek szkolnych, [...] stara się przy

${ }^{4}$ Warto porównać korelacje między krzewieniem znajomości i podnoszeniem rangi polszczyzny a rozwojem polskiego ruchu narodowego z ustaleniami dotyczącymi genezy upowszechniania języka czeskiego w XIX wieku i związków tego zjawiska z formowaniem się czeskiego narodu (zob. Hroch, 2020, s. 83-93). 
każdej sposobności ośmieszyć, nazywając go »z Niemca Polakiem«, choć [...] spomiędzy starszych narodowców prawie każdy przechodził taką [...] przemianę" (s. 54). Zwraca więc uwagę na kluczowe tu zagadnienie wyboru identyfikacji, lub raczej — jej świadomej zmiany. Przyznaje się do niej również Cinciała:

Andrzej Kotula, później notariusz w Cieszynie, Paweł Stalmach, redaktor w Cieszynie, Jerzy Heczko, pastor w Ligotce itd., [...] byli Niemcami, bo nas wychowanie gimnazjalne z Polaków zrobiło Niemcami. [...] Szczęśliwemu trafowi [podkr. K.S.] mają tylko powyżej mianowani mężowie do zawdzięczenia, że [...] mówili i pisali [...] polskim językiem (Cinciała, 1931, s. 38).

Co ciekawe, samego Cinciałę do zainteresowania się tym ostatnim skłonił Morawianin, prawnik Ludwik Klucki. Wymownie charakteryzuje ową metamorfozę regionalista Władysław Sosna:

Potrzebny mu [Kluckiemu - K.S.] był „tutejszy” pomocnik biurowy, potrafiący się rozmówić i napisać po polsku stosowny dokument dla klienta. A tu okazało się, że on [...] stał się „,szkopyrtokiem” ([w miejscowym narzeczu - K.S.] oportunistą, renegatem), który z językiem ojczystym, szczególnie w piśmie, nie najlepiej sobie radzi. Perswazja dr. Kluckiego okazała się nader skuteczna. Jak napisał Cinciała, od 12 X 1845 r. mówił i pisał już tylko po polsku, chłonął polskie książki niczym wysuszona gąbka (Sosna, 1998, s. 8-9).

\section{„Przebudzenie”, czyli o „odwiecznej” narodowości}

Znamienna jest powyższa plastyczna metafora, obrazująca niezaspokojone pragnienie, a więc elementarną potrzebę. W podobnym duchu pisze Andrzej Kotula: „Co do poczucia narodowego byliśmy tedy do roku 1848 niby martwi, zdrętwiali, niechcący słyszeć własnego imienia” (Kotula, 1964, s. 57). W tym świetle więź z polskością sprawia wrażenie nieodzownej do życia oraz jednoznacznego identyfikatora, zmiana przekonań zaś - metanoi, transformacji duchowej. Dochodzi tu do głosu intrygujący paradoks czy też napięcie między rozmyślną przemianą (pionierzy ruchu wskazują, że dojrzewali do niej za pośrednictwem lektur) ${ }^{5}$ a przeświadczeniem, jakoby „czucie polskie” było naturalne, esencjonalne, nieledwie wrodzone, lub przynajmniej nadane u zarania niczym imię (i uświęcone podobnie jak imię przez chrzest).

Użyte przez Kotulę porównanie do letargu versus ożywienia pochodzi z zestawu synonimicznych przenośni określających szerzenie się identyfikacji z kulturą i narodowością polską, typu „przebudzenie”, „odrodzenie”, „odzyskiwanie

5 „Czytający zaczerpnęli u źródła, niecili ducha narodowego u nieczytających i tak ta świadomość narodowa rosła" (Wantuła, list bez daty do K.L. Konińskiego, cyt. za: Koniński, 1938, s. 81). 
świadomości”, „,przejrzenie na oczy”; np. Tadeusz Dyboski w Pamiętniku Czytelni Ludowej z 1912 roku wyłuszcza misję tej instytucji: „wśród ludu dawnej krainy Piastowskiej wzniecić uśpioną polskość" (Dyboski, 1912, s. 5). Owe figury retoryczne sugerują odbiorcy nie konstrukcyjny, lecz „odwieczny” charakter tożsamości narodowej, której poczucie uległo zaledwie stłumieniu (zob. np. Kubica, 2011, s. 38 - 39). Działacze polscy stawiali znak równości między trwaniem wśród ludu języka polskiego - podtrzymywanym m.in. dzięki wzmiankowanym już protestanckim, a później i katolickim wydawnictwom religijnym - a nieuświadamianą więzią z tzw. macierzą (zob. np. Pilch, 1974, s. 43-44). Więź ta miała istnieć „Z dziada pradziada”, mimo iż Śląsk już przed połową XIV wieku znajdował się poza granicami Polski. I ponownie: z jednej strony sami „budziciele” przyznają się do internalizacji w pierwszej kolejności polskiej historii i spuścizny kulturalnej, $\mathrm{z}$ drugiej natomiast $\mathrm{w}$ ich tekstach dominują metafory odwołujące się do biologiczno-organicystycznego rozumienia narodowości, np. autor Pamiętnika Czytelni Ludowej z 1887 roku wyraża dumę, że „lud tutejszy poczuł w żyłach swoich tętniącą dawną krew polską" (s. 10).

Jeszcze w połowie XX wieku ksiądz ewangelicki Karol Kotula nadmienia, iż choć tzw. Zaolzie zostało - wbrew kryterium etnicznemu — przydzielone Czechosłowacji, praca oświatowa w tej części regionu nie poszła na marne, gdyż ów teren odegrał doniosłą rolę „, narodowym odrodzeniu ludu śląskiego [tj. cieszyńskiego - K.S.]” (Kotula, 1998, s. 94). Co więcej, pojęciem „odrodzenia narodowego" operują nawet badacze i regionaliści różnych pokoleń (zob. np. Hierowski, 1938, s. 2; Dawid, 2005, s. 233). Tymczasem mamy, oczywiście, do czynienia z innym procesem - unarodowieniem ludu, czyli przekształceniem świadomości regionalnej (odnoszącej się do niegdysiejszego Księstwa Cieszyńskiego) w narodową (zob. np. Kadłubiec, 1997, s. 365). Trzeba dodać, że kulturę regionu postrzegano (notabene, do dziś taka optyka zdaje się przeważać) w kategoriach folkloru, toteż wymagała ona legitymizacji przez kulturę ,wyższą". Funkcję tę pełniła najpierw kultura czeska, potem niemiecka, w końcu dowartościowywała Cieszyńskie mitologizowana i apoteozowana Polska, którą postrzegano przez pryzmat osiągnięć kulturalnych i wzniosłej historii. Jak przekonuje autor Pamiętnika Czytelni Ludowej z 1887 roku, „dziś Szlązacy czują, że są odłamem wielkiego narodu polskiego, który, lubo pogrążony $\mathrm{w}$ niewoli, do niedawna jednak światłem swym $\mathrm{w}$ powszechnym pomroku w podziwienie wprowadzał i ciągle zadziwia inne narody europejskie" (s. 7-8). Działacze przydawali godności miejscowemu narzeczu, akcentując jego staropolską formę, ,zgoła tak[ą], w jakiej Kochanowski i jemu spółcześni pisali" (Stalmach, 1910, s. 147). Sama Polska - nieistniejąca wówczas na mapach i będąca raczej fantazmatem - jawiła się niczym ziemia obiecana (zob. np. Zabawski, 1934), w której Cieszynianie zyskają należną im pozycję jako pełnoprawni obywatele. 


\section{Rozbieżności polityczne, wyznaniowe i tożsamościowe}

Skoro narodowa tożsamość (poczucie wspólnoty grupy etnicznej połączonej kulturą duchową i materialną) stanowi konstrukt, historia - ciąg zdarzeń wyselekcjonowanych i zobrazowanych przez osoby do tego powołane, a tradycja ,jest w niemałym stopniu wynalazkiem narodowych ideologów" (Szacki, 1997, s. 19), warto dopytać o panujący wśród cieszyńskich działaczy model narodu i tożsamości narodowej. Ponieważ po utworzeniu Austro-Węgier i wprowadzeniu w ich konstytucji swobód obywatelskich polski ruch krzewił się wśród elit chłopskich, w rzeczonym modelu brak nawiązań do demokracji szlacheckiej; z kolei odmienność dziejów Śląska i obszaru Królestwa Polskiego skutkowała nieobecnością wątków mesjanistycznych i insurekcyjnych. Zdaniem Grzegorza Studnickiego polski nurt narodowy w regionie, wychodząc od kwestii językowych, skierował się ku etnonacjonalizmowi, później reprezentowanemu przez endecję (Studnicki, 2015, s. $100-101)$.

Co do spraw społecznych — twierdzi Zofia Kirkor-Kiedroniowa, działaczka narodowa i oświatowa przybyła na Śląsk Cieszyński w 1905 r. — różnice mogły być tylko w sądach o stosunkach i polityce w Galicji i w ogóle w Polsce, boć o ile chodziło o Księstwo Cieszyńskie, to polscy narodowcy wszelkich odcieni innego programu jak demokratyczny [...] mieć nie mogli. Nie było wszak na Śląsku polskiej szlachty, [...] fabrykantów, kapitalistów (Kirkor-Kiedroniowa, 1988, s. 39).

Chociaż niewielkie rozwarstwienie społeczności etnicznie polskiej wzmacniało rodzącą się tożsamość narodową, trzeba dopowiedzieć, że omawiany ruch był podzielony ideologicznie i wyznaniowo i na początku XX wieku istniało kilka konkurujących stronnictw (Polskie Zjednoczenie Narodowe, skupiające dawnych narodowców i ludowców, Związek Śląskich Katolików oraz Polska Partia Socjalno-Demokratyczna). Niemniej już w memuarach Cinciały i Stalmacha — dawnych kolegów gimnazjalnych - na plan pierwszy często przebijają wzajemne animozje, wynikające nie tylko z chęci przyznania sobie większych zasług, lecz także $\mathrm{z}$ antagonizmu stronnictw katolickiego i ewangelickiego. W rezultacie Zdzisław Hierowski zauważa, że przeczytawszy oba teksty, „stajemy dopiero bezradni, zdezorientowani, zaskoczeni. Daleko nam do ujęcia całości, przekonujemy się, że dopiero od poznania tych pamiętników musi się zacząć mozolne, ostrożne tropienie prawdy" (Hierowski, 1938, s. 2).

Jeśli chodzi o zatargi międzywyznaniowe, przywołany już Janik przybliża przyczyny niesnasek między księżmi katolickim Józefem Londzinem a ewangelickim Franciszkiem Michejdą - czołowymi orędownikami interesów narodowych - i równocześnie zaznacza, że sporo duchownych obu denominacji starało się dla dobra wyższej, wspólnej sprawy zachować neutralność. Zresztą podziały narodowe i polityczne krzyżowały się z konfesyjnymi; wśród ewangelików 
duże wpływy w drugiej połowie XIX wieku zyskał obóz antypolski superintendenta diecezji, ks. Theodora Haasego, po którym zwolenników przejął Józef Kożdoń - lider tzw. ślązakowców, głoszący etniczną odrębność Ślązaków oraz wierność monarchii habsburskiej.

W tym kontekście należy wrócić do języka jako czynnika uznawanego za przesądzający o identyfikacji narodowej; przy czym według pionierów polskiego ruchu znaczenie miał ten język, w którym się wyrosło. W emocjonalnym tonie pisze o ówczesnych dylematach tożsamościowych (z perspektywy drugiej połowy $\mathrm{XX}$ wieku) redaktor Henryk Jasiczek: „Pogardzany i spychany do roli potrzeb gminu, język polski odżywał, wzruszał i niepokoił, zwłaszcza kiedy wypowiadały go usta matki [...]" (Jasiczek, 2016, s. 17-18). Co prawda badacze podkreślają wagę wychowania w lokalnych tradycjach i w polskim języku jako fundamentu przywiązania do dziedzictwa narodu (zob. np. Bogus, 2009, s. 31), lecz samo zachowanie zwyczajów i języka (często w formie dialektu) nie wystarczało, by czuć ową łączność. Z jednej strony przecież „urabiano się” na Niemców w szkołach, z drugiej np. w wydawanym przez ks. Haasego proniemieckim „Nowym Czasie” stosowano język polski - zdarzały się wszak sytuacje, że ktoś nie umiał mówić po niemiecku, a uważał się za Niemca (zob. np. Wantuła, 2003, s. 189—190), aczkolwiek polscy działacze traktowali takie przypadki jako fałszywą świadomość. W dość wyważony sposób, choć sugerując własną ocenę tego fenomenu, postawę typowego sympatyka Kożdonia unaocznia w memuarach ksiądz ewangelicki Andrzej Buzek:

Nie zapierał się więc polskiego pochodzenia, ale akcentując, że jest śląskim Polakiem, dawał do zrozumienia, że [...] orientuje się politycznie w kierunku niemieckim. O takich Polakach śląskich mówili tu wówczas Niemcy [...] ,,po niemiecku myślący Polak". Zawoła ktoś: co za dziwaczne określenie! A jednak było wtedy po poniemczonych miasteczkach śląskich dużo takich [...]. Po miastach mówili oni po niemiecku i identyfikowano ich z Niemcami. Po wsiach, gdzie mówili po polsku, określali ich Niemcy nazwą [...] ,przychylni Niemcom Polacy”. W r. 1909 stworzyli oni własne stronnictwo - Śląską Partię Ludową (Buzek, 2009, s. $14-15)$.

Z kolei Janik tłumaczy: „Pracująca ludność niemiecka nie dzieliła nienawiści nacjonalistycznych prowodyrów, liczyła się z polską klientelą i pragnęła zgodnego współżycia. Była to często ludność pochodzenia polskiego, która w miarę wzrostu uświadomienia narodowego na Śląsku często wracała na łono polskości" (Janik, 1929, s. 36). Ta ostatnia metafora znów odsyła do wyobrażenia Polski jako matki, z którą spajają autochtonów w Cieszyńskiem więzy krwi i która czeka na nawróconych synów marnotrawnych. Jak perswaduje autor pierwszego Pamiętnika Czytelni Ludowej (1887): „,[P]ostęp narodowy na Szląsku ani dziś, ani dawniej nie byłby możliwym, gdyby nie wolno było liczyć na to, że się pozornego Niemca, choć z rodu Polaka, wytrwałem i umiejętnem przekonywaniem, oświecaniem i rozgrzewaniem doprowadzi [...] [do] poczucia swej polskiej narodowości" (s. 54). 


\section{Szkoła jako posterunek i pepiniera polskości}

Jak już zasygnalizowano, rozstrzygającą rolę odgrywały placówki oświatowe, a działacze polscy byli zgodni, że na wpływ niemieckich gimnazjów trzeba „uodparniać”, zatem największa odpowiedzialność ciążyła na nauczycielach szkół ludowych. Dopiero w 1885 roku z inicjatywy Stalmacha powołano Macierz Szkolną dla Księstwa Cieszyńskiego, dla której priorytet stanowiło utworzenie polskiego gimnazjum. Otwarto je dziesięć lat później jako placówkę prywatną, a macierz zakładała następnie własne szkoły ludowe, ochronki itp. Gimnazjum Polskie w Cieszynie zyskało opinię kuźni polskości, co w Pamiętniku śląskiego nauczyciela w patetyczno-tyrtejskich rejestrach opiewa Jan Żebrok:

[M]ieliśmy się stać tym pierwszym zastępem bojowym w walce o nasze prawa narodowe, o nasz język, o lepszy byt wiejskiego i robotniczego ludu śląskiego, [...] awangardą inteligencji polskiej na Ziemi Cieszyńskiej. Uświadomienie narodowe wśród nas wyrabiała nie tylko szkoła i wychowawcy-profesorowie, ale i władze austriackie, a przede wszystkim Niemcy cieszyńscy, którzy za wszelką cenę chcieli utrącić tę pierwszą polską placówkę [...] (Żebrok, 2001, s. 17).

Sam wybór szkoły dla dziecka często wywoływał u rodziców dramatyczne rozterki, podlegali oni bowiem sprzecznym naciskom. Obrazuje to choćby ks. Buzek:

Tak Polakom, jak Niemcom chodziło wtedy o to, by jak najwięcej młodzieży kształcić w swoich szkołach. [...] nakłanialiśmy Zabystrzana, by zapisał swego syna do Gimnazjum Polskiego w Cieszynie, co on obiecał uczynić. Ten zaś właśnie chłopiec, [...] mimo że ojciec pod silną presją swoich niemieckich pracodawców w hutach trzynieckich zapisał go po wahaniach i walkach z własnym sumieniem do cieszyńskiej niemieckiej szkoły wydziałowej, wyrósł na dzielnego nauczyciela polskiego i zmarł w r. 1956 na posterunku szkolnym w Trzyńcu (Buzek, 2009, s. 108).

Podniosła metafora „śmierci na posterunku” służy uwypukleniu poświęceń i dzielności niezbędnych w pracy oświatowo-narodowej. Na ogół również polscy badacze - nie bez tendencyjności — podkreślają u nauczycieli zaangażowanych $\mathrm{w}$ ten ruch ofiarność, poczucie powołania, wreszcie determinację, by mimo przeszkód działać w różnych sferach na rzecz kultury polskiej (np. Dawid, 2009, s. 69-70). Pionierów spośród tych aktywistów apoteozuje ks. Karol Kotula, eksponując ich godność i kulturę osobistą:

[C]i wszyscy nauczyciele, którzy [...] musieli się przeciwstawiać niemieckim wpływom władz [...], górowali znacznie nad otoczeniem i choć byli nauczycielami na wsi, wcale nie schłopieli [...]. Wzniosłe ideały i bój o wolność i polskość wynosiły ich nad poziom (Kotula, 1998, s. 47). 


\section{„Na służbę naszemu ludowi”}

Mówiąc o powołaniu, trzeba wrócić do problemu metamorfozy i jej uzasadniania u tzw. pierwszych szermierzy polskości. Dochodzenie do niej wiązało się nie tylko z mozolnym samokształceniem, lecz także ze sprzeciwem wobec różnych przełożonych i z ograniczeniem aspiracji. Przejmowanie przez młodzież w gimnazjach niemieckiego języka i kultury stanowi jeszcze pod koniec XIX wieku zjawisko na tyle naturalne, iż Jan Stanisław Bystroń nie waha się nazwać decyzji Stalmacha i Cinciały o ,porzuceni[u] utartej drogi kariery życiowej i powro[cie] do polskości” (Bystroń, 1931, s. VII) w latach 40. gestem bez mała rewolucyjnym. W przytoczonym cytacie pojawia się następna wymowna metafora: polskości jako czegoś źródłowego, pierwotnego; stąd identyfikacja z nią oznacza nie przyjęcie nowej jakości, lecz odkrycie tego, co się utraciło (,przebudzeni” zaczynają dostrzegać, że dotąd byli „,szkopyrtokami”, odszczepieńcami), przede wszystkim zaś oznacza pójście pod prąd, heroizm. Jak objaśnia antropolożka Grażyna Kubica: „Wymiar etyczny zmienia arbitralność tego wyboru w jego moralną konieczność, a nawet supererogację, czyli czyn chwalebny" (Kubica, 2011, s. 39). Potwierdza to w pamiętniku Andrzej Kotula: „Gdy [...] krzewiciele poczucia narodowego poczęli pisać dla ludu polskiego na Śląsku, przypominając mu należenie jego do wielkiego narodu polskiego, pojęli światlejsi od razu prawowitość takiego postępowania [...]" (Kotula, 1964, s. 57). Rangę moralnego obowiązku nadano więc nie tylko zmianie własnych przekonań, lecz także dopomaganiu indyferentnym ziomkom w dojrzeniu do świadomości narodowej.

Jan Wantuła - wybitny bibliofil, historyk samouk, publicysta, a zarazem robotnik w hucie — wspomina, że zafascynowany w dzieciństwie ,Werdauskimi Wiadomościami Misyjnymi” (dodatkiem do „Zwiastuna Ewangelicznego”), postanowił nawracać pogan. Z dystansu lat ocenia, że marzenie poniekąd się spełniło, ostatecznie bowiem pracował ,na polu wewnętrznej misji, między białymi, u nas...” (2003, s. 21). Owo ,u nas” można uznać za słowo klucz, gdyż rewersem oddania ideologii jest w omawianych tu przypadkach ideologia oddania - upatrywanie powołania w służbie autochtonom. Już Stalmach wyznaje: „Porzuciłem rojone nadzieje i [...] widziałem jakby przeznaczenie swoje do pracowania wyłącznie dla ludu, dla jego oświaty przez pracę piśmienną" (Stalmach, 1910, s. 277). Wantuła w przemówieniu agitacyjnym — przed niedoszłym plebiscytem mającym zadecydować o przynależności państwowej Śląska Cieszyńskiego — perswaduje:

I ja w głębi mej natury jestem jak i wy też zachowawczy, też mi się zdaje czasem, że lepiej by było tak po dawnemu: nie kłopotać się, siedzieć w domu, patrzeć [ciesz. 'pilnować' — K.S.] swojej pracy. [...] ale boję się, że [...] po czasie młodsze pokolenie, wiedząc o mnie, że byłem w stanie dziś coś zrobić, [...] wypali mnie, [...] żem nie wykonał mego obowiązku [...] (Wantuła, 1918). 
Co najistotniejsze, nie chodzi o poświęcenie przedstawicieli klas wyższych, którzy „wstępują w lud” z kagankiem oświaty — jeśli „,budzenie” wśród mieszkańców regionu „czucia narodowego” rozumiano jako odkrycie polskich korzeni całej zbiorowości, to owa praca na rzecz ludu i z ludem oznaczała na ogół dla jednostki skierowanie się ku własnym korzeniom. Ideologię służby „swoim” eksplikuje w miniaturach wspomnieniowych pochodzący z Cieszyńskiego socjolog Jan Szczepański: otóż każdy powinien oddawać społeczeństwu to, co z niego zaczerpnął $\mathrm{w}$ trakcie enkulturacji $\mathrm{w}$ tzw. instytucjach pierwotnych, w kręgu rodzinno-sąsiedzkim i szkolnym (Szczepański, 2013, s. 8). (Uczony wyprowadza stąd oczywisty imperatyw uzmysłowienia sobie owego nabytego bagażu kulturowego, w tym aksjologicznego).

Poczucie obowiązku zwracania środowisku lokalnemu tego, co się otrzymało, wedle memuarów przyświecało zarówno starszemu, jak i młodszemu pokoleniu. Jan Kubisz tak charakteryzuje ks. Otta: ,[U]rządza wieczory czwartkowe i uczy, jak myśleć, jak czytać i jak miłować ten lud, z którego się wyszło, i jak mu służyć należy" (Kubisz, 1928, s. 304). Wantuła napomyka, że zrezygnował z oferowanej mu kariery redaktora, by nie opuszać „swoich”, a jego postawę afirmuje zaprzyjaźniony z nim Karol Ludwik Koniński, akcentując wyższość działacza z ludu nad takim, który do ludu się ,zniża”: „,Z]ostawszy pomiędzy swoimi, blisko ziemi, człowiek tego rodzaju (przez to właśnie, iż nie człowiek książkowy, ale [...] wszechstronny, uczestnik pospólnej pracy, przy tym działacz, sercem oddany sprawom wyższym [...]) powinien był stać się punktem intensywnego promieniowania idealistycznego w środowisku rodzimym" (Koniński, 1955, s. 262-263).

Wantuła przyznaje jednak, iż jego decyzja wynikała po części z lęku przed wyobcowaniem z własnej grupy społecznej czy też wspólnoty lokalnej, a obawy te przełożyły się też na obiekcje, czy wysłać potomka na uniwersytet. Dziś można osądzić, że byłaby to chybiona decyzja, gdyż syn Andrzej osiągnął znacznie więcej niż on - został profesorem teologii i zwierzchnikiem Kościoła Ewangelicko-Augsburskiego w Polsce. Niemniej jeszcze w czasie studiów ojciec nakłania go (w liście z 25 listopada 1930 roku) do pracy właśnie „wśród swoich” na Śląsku (,ja też z tym, byś wyrósł na służbę naszemu ludowi, dałem Cię kształcić" [Wantuła, 2017, s. 157]), aby zaciągnięty u losu dług oddał ludziom, którym z przyczyn życiowych zabrakło szansy na edukację. Gustaw Morcinek, choć zdobył popularność w skali kraju i obracał się w kręgach władz, powtarzał, że swoim pisarstwem — na ogół podejmującym tematykę górniczą i śląską — rewanżuje się kolegom z kopalni w Karwinie. Ci bowiem urządzili składkę, żeby opłacić edukację garnącego się do książek młodzieńca w seminarium nauczycielskim (zob. np. Heska-Kwaśniewicz, 1988, s. 45).

O ile np. Stalmach utrzymuje, że jego nie trzeba było do służby „swoim” zachęcać („Przyznać się muszę, że pragnąłem pracować nade wszystko dla ludu swego we własnej krainie, i widocznie Opatrzność tak zrządziła, że postanowiłem nie opuszczać Cieszyna" [Stalmach, 1910, s. 220]),, o tyle z pamiętnika Cinciały wynika, że jednak postawa taka nie należała do powszechnych. Jako członek zarządu

136 Towarzystwa Naukowej Pomocy oponował on przeciw zapomogom, tłumacząc, że 
organizacja ta ma wspierać młodzież w wychowaniu się „na dobrych narodowców, którzy by byli obowiązani po skończonych studiach, o ile tylko można, osiadać na Śląsku i tu nad oświatą i dobrem ludu pracować" (Cinciała, 1931, s. 145), by odwdzięczyć się za dobrodziejstwa temu i innym stowarzyszeniom. Mówiąc metaforycznie: zdecydować się na powolne, uparte i znojne — jak to określa tytuł wspomnień Szczepańskiego — „wrastanie korzeniami w ziemię”.

\section{Poświęcenie i pozytywizm}

Jak łatwo przewidzieć, idealizacji dokonują nie tylko autorzy memuarów, uwypuklający m.in. własną bezinteresowność (,[N]ie kłaniałem się cudzym bogom, ale służyłem, siedząc na progu ojczystego domu i ucząc dzieci polskiego ludu. I to mi dziś jedyną nagrodą, że mi tak służyć dano" [Kubisz, 1928, s. 312]), lecz także polscy badacze (,,[P]owstanie polskiego ruchu nie było możliwe bez oddanych sprawie »szermierzy«, bez ich intelektualnych, moralnych, organizatorskich walorów oraz ich ofiarnego trudu, a kiedy trzeba — twardych zmagań” [Buława, 1997, s. 7]). Istotnie, jednym z lejtmotywów analizowanych tekstów jest gorliwa aktywność pro publico bono na przekór okolicznościom, która nierzadko nosi znamiona bohaterstwa, jak widać to w pamiętniku ks. Pindóra, zmuszonego pracować u boku ks. Haasego w Cieszynie. Nadmieniając o zamiarze superintendenta, by powierzyć mu redakcję „Nowego Czasu”, memuarysta pisze: „Byłem [...] przerażony, ja przecież przeciwko własnemu narodowi nie mogłem i nie chciałem pisać" (Pindór, 1932, s. 59) i — według swojej relacji — stanowczo oponuje. Podobnie bez względu na konsekwencje ze strony przełożonego postanawia odprawić nabożeństwo na otwarcie gimnazjum polskiego nie w szkole, ale w kościele.

Co jednak symptomatyczne, owa ofiarna służba nie powinna oznaczać męczeństwa ${ }^{6}$; w świetle pamiętników jawi się ona jako o tyle romantyczna, o ile entuzjastyczna i wzniosła, lecz de facto chodzi o zdecydowanie pozytywistyczną, oświatowo-gospodarczą ,pracę u podstaw” w organizacjach kulturalnych i społecznych. Można ten model wyjaśniać wzmiankowanym brakiem szlacheckiej kultury intelektualnej i pragmatyczno-utylitarnym nastawieniem warstw niższych wszak ,warunki musiały "przystosować« inną grupę, by inteligencją się stała. Cechą świadomości tej »nowo powstałej« społeczności był specyficzny kodeks wartości preferowanych" (Bogus, 2013, s. 180-181). Na określenie owego kodeksu można przywołać pojęcie odsyłające do obyczajowości i wytycznych aksjonormatywnych, które sami autochtoni w mitologizujących narracjach kojarzą ze Śląskiem Cieszyńskim. Mowa o pojęciu etosu protestanckiego, reprezentowanego w tym wypadku przez lud. Edward Buława — znów nie bez idealizacji — kładąc nacisk

${ }^{6}$ To raczej dopiero konflikt z Czechami o zachodnią część Śląska Cieszyńskiego przywołał wzorce martyrologiczne (zob. np. Kirkor-Kiedroniowa, 1988; a także przypis 2). 
na rzetelność, systematyczność i poczucie odpowiedzialności, które przebijają ze „Sprawozdań Towarzystwa Domu Narodowego” z dekady 1887—1897, twierdzi, że ,[t]aki styl pracy, odpowiadający plebejskiej mentalności Ślązaków, zaszczepiany [był] polskim towarzystwom na Śląsku Cieszyńskim nie tylko przez [...] działaczy, ale przede wszystkim przez rytm codziennej pracy [...]" (Buława, 1997, s. 108).

W memuarach także podkreśla się powszednią, szarą, a zarazem konkretną pracę metodą małych kroków, m.in. w zdobywaniu kolejnych przyczółków dla języka polskiego (np. w gospodach w Cieszynie czy w sprawozdaniach dla władz oświatowych; zob. np. Janik, 1929, s. 30). Nawet Klemens Matusiak — wojskowy stojący na czele przewrotu w cieszyńskim garnizonie austriackim w 1918 roku wypowiada się w takim duchu: „Uprzytomniliśmy sobie jednak, że marzenia wieków ziszczą się wtedy, jeżeli zakaszemy rękawy do pracy i zrozumiemy, że zaniedbanie choćby nawet najmniejsze może przynieść nam straty niepowetowane" (Matusiak, 1964, s. 230). Wantuła w liście do Konińskiego trafnym porównaniem przekonuje, że nie liczą się jedynie wybitni przywódcy, lecz każde ogniwo: „Tacy jak ja, co z masy, z tłumu wyrośli, ale się z niej nie wyłączali, [...] nadawali kierunek ludowi. Podoficerowie nieodróżniający się zewnętrznie od zwykłego żołnierza nie mniej ważną rolę spełniają niż generałowie" (cyt. za: Koniński, 1938, s. 81).

Jako uosobienie pozytywistycznego działacza, a zarazem „wzór śląskiego chłopa", Kubisz przedstawia Franciszka Górniaka, właściciela cegielni, który był poza podziałami partyjnymi, gdy zaś własnymi rękami dorobił się bogactwa, nie zagarnął go dla siebie, tylko dzielił się ze społeczeństwem - wspierał polskie organizacje i prasę oraz wydatnie przyczynił się do budowy Domu Narodowego (Kubisz, 1928, s. 299). Inną typową cechą postawy pozytywistycznej jest legalizm, którym Sosna tłumaczy niepowodzenia Cinciały w pracy społecznej pod koniec życia: „Zbyt był skrupulatny, zbyt realistyczny, wymagający dla siebie i innych, a przede wszystkim działający ściśle w granicach prawa" (Sosna, 1998, s. 9). Wszakże zasłużył się pracami etnograficznymi oraz zgromadzeniem źródeł do dziejów Śląska Cieszyńskiego, co wpłynęło na szerzenie się nie tylko identyfikacji miejscowej ludności z polską wspólnotą narodową, lecz także dumy z dziedzictwa własnego regionu (zob. np. Buława, 1997, s. 111).

\section{Zakończenie}

W przypadku Śląska Cieszyńskiego nie mamy więc zasadniczo do czynienia $\mathrm{z}$,emisariuszami” - poszlachecką inteligencją z byłego zaboru rosyjskiego, udającą się na peryferie, by oświecać lud — i z narzucaniem optyki centrum (zob. np. Nycz, 2010, s. 180), choć oczywiście, utożsamiając się z Polską, utożsamiano się z panteonem jej bohaterów oraz nierzadko obcymi Ślązakom tradycjami i wartościami (typu powstania narodowe). Warto tu dodać, że ks. Otto, przybyły z Warszawy, w świetle pamiętnika Kubisza doskonale wpasowywał się w mentalność i kulturę 
panujące w Cieszyńskiem. Niemniej trochę działaczy oświatowych (z Towarzystwa Szkoły Ludowej) i inżynierów przyjeżdżało tam ze Lwowa i okolic, a Mieczysław Jarosz określa ich lapidarnie: „Byliśmy szczupłą grupką emigranckiej inteligencji, którą losy rzuciły na kresy ostrawskie" (Jarosz, 1963, s. 33). Trzeba pamiętać, że z punktu widzenia państwa narodowego pogranicze wydaje się podejrzane, niepewne, nieczyste w swej heterogeniczności, kiedy jednak następuje jego ideologiczne przeobrażenie w „kresy”, dostaje się ono na piedestał jako bastion walki o esencję narodowej tradycji (zob. np. Hudzik, 2011, s. 236).

Nieco z góry spogląda na owych cieszyńskich „kresowian” przywoływany już dr Michał Janik, którego zaproszono, by objął posadę w gimnazjum polskim. Pragnie on co prawda, by Cieszyńskie miało twórczy wkład w kulturę narodową, i docenia lokalnych autorów, ale żeby te zadatki ,wzmocnić”, on, przybysz, pisze kilka poematów na motywach lokalnych podań historycznych. Podobnie Mieczysław Jarosz jest początkowo traktowany z nieufnością, lecz ostatecznie wspólna „pozytywistyczna” działalność pozwala mu zbliżyć się do autochtonów („Po z górą pięciu latach ciężkiej [...] pracy rozstawałem się z ludźmi, z którymi zżyłem się w codziennej orce, w nieustępliwej walce o prawa ludu polskiego" [Jarosz, 1963, s. 36-37]). Analogiczne skrócenie dystansu sygnalizuje Zofia Kirkor-Kiedroniowa, sięgając w memuarach po topos skromności: gdy po jej przemówieniu na wiecu we Lwowie w intencji polskich szkół w Cieszyńskiem ,,prof. Romer zaczął od charakteryzowania mnie jako »duszy« Śląska, [u]czułam takie zażenowanie, że ukryłam twarz w dłoniach. Wszak nie »duszą« Śląska jestem, tylko służebnicą" (Kirkor-Kiedroniowa, 1988, s. 105).

Zasadniczo jednak z uwagi na swoistość historyczną, społeczną i kulturową regionu polski ruch narodowy miał oblicze plebejskie, oddolne, będąc pochodną emancypacji politycznej i intelektualnej ludu, który zyskał możliwość samostanowienia. Dzięki temu odbiorcy zabiegów „budzicieli” nie zostają zinstrumentalizowani, „budzicielami” są bowiem równi im chłopi i robotnicy. Jak zaznacza Henryk Życzyński, „Działacze narodowi [w Cieszyńskiem — K.S.] wyrastali z ludu, związani z nim tysiącem nici, a pracując z nim [podkr. K.S.] i dla niego, razem z nim rośli i zmuszali ogół iść z sobą bezwiednie" (cyt. za: Miękina, 1991, s. VIII). Warto w tej „bezwiedności” dostrzec efekt dyskursu ideologicznego, budzącego w podmiotach, na które oddziałuje, poczucie, że ich własne interesy są zgodne $\mathrm{z}$ ową propagowaną ideą. Taki dyskurs występuje również w tekstach typu pamiętnikarskiego, wykorzystywanych do formowania poczucia tożsamości zbiorowej i jej umacniania. Ale można je rozpatrywać nie tylko jako przykład strategii retorycznych w służbie ideologii - ukazują one też, jak ta ostatnia łączy się z ideologią służby: jak sprawa narodowa przenika się z regionalną i ludową.

Odczucia narodowe i patriotyzm kojarzono $\mathrm{z}$ wiernością tradycji ludowej przodków: „Inteligent śląski, wywodzący się z ludu, jeśli nie chciał się wynarodowić, unikał wysferzania się z reszty społeczeństwa. Szukając w nim zaplecza i oparcia, solidarność tę starał się umocnić [...], pomagając mu zdobyć świadomość swej roli i zadań w warunkach, które przed nim kładzie historia" (Jasiczek, 2016, s. 18). W tej podniosłej retoryce „misji dziejowej” nie chodzi 
o komunistyczną ideologię dotyczącą roli proletariatu, lecz o wyzwania, które przyniósł wiek XX. Nie pomijając takich dowodów poczucia polskości jak uformowanie w Cieszynie Legionu Śląskiego w 1914 roku czy podawanie narodowości polskiej w spisach ludności w okresie okupacji, warto zaakcentować pewien rezultat rozwoju polskiego ruchu narodowego, który zdaje się owocować do dziś. Byłaby to rozwinięta przez ludność tzw. warstw niższych tradycja działalności kulturalno-oświatowej i stowarzyszeniowej (zob. np. Spyra, red., $2001)^{7}$ oraz samokształcenia ${ }^{8}$. I wreszcie ślady rozumienia pracy wśród „swoich" w kategoriach zobowiązania moralnego. Jak pisał w 1988 roku miejscowy redaktor o zasłużonym historyku regionu, bibliofilu, działaczu spółdzielczym i kulturalnym, samouku Józefie Pilchu, wyjaśniając jego skromność i ograniczenie opracowań - mimo szerokiej wiedzy — do tematyki lokalnej: „,W]idzę w tym przejaw traktowania pisarstwa za [!] rodzaj społecznej służby, właśnie za spłacanie zaciągniętego długu" (Danel, 1988, s. 4).

\section{Bibliografia}

Bogus M., 2009: Model kariery polskiego nauczyciela na Śląsu Cieszyńskim. W: Tradycje kształcenia nauczycieli na Śląsku Cieszyńskim. Od Polskiego Seminarium Nauczycielskiego do Filii Uniwersytetu Ślaskiego w Cieszynie. Red. W. Korzeniowska, A. Mitas, A. Murzyn, U. Szuścik. Katowice: Wydawnictwo Uniwersytetu Śląskiego, s. $25-42$.

Bogus M., 2013: Nauczyciele szkót ludowych Śląska Cieszyńskiego w XIX i na początku XX wieku. Uwarunkowania prawne i zawodowe. Częstochowa-Czeski Cieszyn: Wydawnictwo AJD.

Bonczek A., 1930: Pamiętnik. Stonawa: Stowarzyszenie Spożywcze dla Robotników i Rolników.

Broda J., 1978: Zapiśniki chłopów śląkich. „Regiony”, nr 1, s. 58—90.

Broda J., 1997: Pamiętniki inteligencji polskiej. „Pamiętnik Cieszyński”, t. 12, s. 91—92.

Buława E., 1992: Przed powstaniem Macierzy. W: Macierz Szkolna wczoraj i dziś. Biuletyn historyczny z okazji 70. rocznicy założenia Macierzy Szkolnej w Czechosłowacji. Red. O. Matuszek. Czeski Cieszyn: ZG PZKO, s. 8-20.

Buława E., 1997: Pierwsi szermierze ruchu narodowego na Śląsku Cieszyńskim. Cieszyn: Pro Filia.

Buzek A., 2009: Z Ziemi Piastowskiej. Wspomnienia pastora. Cieszyn: Oddział Polskiego Towarzystwa Ewangelickiego.

${ }^{7}$ Co znamienne, obecnie na Śląsku Cieszyńskim działa dwa razy więcej organizacji pozarządowych niż średnio w kraju (zob. np. Gruszczyk, 2019).

8 Por. np.: ,[S]zemat ujęty w Pamiętniku zadaje kłam twierdzeniom, że człowiek bez stosownego wykształcenia [...] nie posiada zdolności do pracy idealnej, umysłowej. Człowiekowi jest już wrodzona natura taka, która nigdy go nie zaspakaja [...], a tym sposobem wytwarzają się naturaliści i samoucy, którzy tak samo są zdolni do wykonywania oprócz pracy fizycznej pracę ideową i duchową" (Bonczek, 1930, s. 101). 
Bystroń J.S., 1931: Od wydawcy. W: Pamiętnik dra Andrzeja Cinciaty, notariusza w Cieszynie (1825-1898). Katowice: Muzeum Śląskie, s. V-XI.

[Cinciała A.], 1931: Pamiętnik dra Andrzeja Cinciaty, notariusza w Cieszynie (18251898). Oprac. J.S. Bystroń. Katowice: Muzeum Śląskie.

Danel R., 1988: Spłacanie dtugu. „Głos Ziemi Cieszyńskiej”, nr 9, s. 4.

Dawid Ł., 2005: Jedna religia, dwie poetyki. Jana Kubisza przygoda translatorska. „Napis”, seria XI, s. 231-244.

Dawid Ł., 2009: Ku nowej formacji nauczycielskiej — z badań nad „Miesięcznikiem Pedagogicznym" (1892-1939). W: Tradycje kształcenia nauczycieli na Ślasku Cieszyńskim. Od Polskiego Seminarium Nauczycielskiego do Filii Uniwersytetu Ślaskiego w Cieszynie. Red. W. Korzeniowska. Katowice: Wydawnictwo Uniwersytetu Śląskiego, s. 69-83.

[Dyboski T.], 1912: Pamiętnik Czytelni Ludowej w Cieszynie 1861-1911. Na 50-lecie skreślit Tadeusz Dyboski. Cieszyn: Czytelnia Ludowa.

Gruchała J., Nowak K., 2013: Dzieje polityczne. W: Śląsk Cieszyński od Wiosny Ludów do I wojny światowej (1848-1918). Red. K. Nowak, I. Panic. Cieszyn: Starostwo Powiatowe, s. 21-164.

Gruszczyk R., 2019: Społeczeństwa obywatelskie na Śląsku Cieszyńskim pod lupq laboratorium. Portal Organizacji Pozarządowych NGO.pl. https://publicystyka.ngo.pl/ spoleczenstwa-obywatelskie-na-slasku-cieszynskim-pod-lupa-laboratorium [dostęp: 10.10.2019].

Heska-Kwaśniewicz K., 1988: Pisarski zakon. Biografia literacka Gustawa Morcinka. Opole: Instytut Śląski.

Hierowski Z., 1938: Trzy pamiętniki. „Poseł Ewangelicki”, nr 15, s. 2.

Hroch M., 2020: Powstanie małych narodów w Europie Środkowej i Poludniowo-Wschodniej. Warszawa: Studium Europy Wschodniej Uniwersytetu Warszawskiego.

Hudzik J.P., 2011: Zrozumieć Śląsk. Różnica kulturowa i granice teorii. „Teksty Drugie”, nr 5, s. 231-243.

Janik M., 1929: Wspomnienia cieszyńskie. W: Księga o Ślasku wydana z okazji jubileuszu 35-letn[iego] istnienia „Znicza”. Red. A. Targ. Cieszyn: nakładem „Znicza”, s. $27-37$.

Jarosz M., 1963: Wędrówki po ścieżkach wspomnień. Warszawa: Czytelnik.

Jasiczek H., 2016: Nasz region i regionalizm. W: Plyniesz, Olzo. Monografia kultury ludowej Ślaska Cieszyńskiego. Red. D. Kadłubiec. Wyd. 2 poszerz. i uaktual. Czeski Cieszyn: Kongres Polaków w Republice Czeskiej, s. 15-22.

Kadłubiec D., 1997: Posłowie. W: E. Buława: Pierwsi szermierze ruchu narodowego na Ślasku Cieszyńskim. Cieszyn: Pro Filia, s. 365-371.

Kirkor-Kiedroniowa Z., 1988: Wspomnienia. Cz. 2: Ziemia mojego męża. Red. A. Szklarska-Lohmannowa. Kraków-Wrocław: Wydawnictwo Literackie.

Koniński K.L., 1938: Pisarze ludowi. Wybór pism i studium o literaturze ludowej. T. 2. Lwów: Wieś.

Koniński K.L., 1955: Robotnik bibliofilem. Przyczynek do bibliofilstwa na Śląsku. W: Idem: Pisma wybrane. Warszawa: Pax, s. 257-263.

Kotula A., 1964: Ze „, Szkoły polszczyzny”. W: Wspomnienia Cieszyniaków. Oprac. L. Brożek. Warszawa: Pax, s. 54-58.

Kotula K., 1998: Od marzeń do ich spetnienia. Wspomnienia z lat 1884-1951. Bielsko-Biała: Augustana. 
Kubica G., 2011: „Chwalebna polskość”. Etyczny wymiar tożsamości ślaskich działaczy narodowych (analiza narracji autobiograficznych). W: Eadem: Ślaskość i protestantyzm. Antropologiczne studia o Śląsku Cieszyńskim, proza, fotografia. Kraków: Wydawnictwo Uniwersytetu Jagiellońskiego, s. 33-48.

Kubisz J., 1928: Pamiętnik starego nauczyciela. Garść wspomnień z życia śląskiego w okresie budzacego się ruchu narodowego w b[ytym] Księstwie Cieszyńskim. Cieszyn: Wydawnictwo Towarzystwa Ewangelickiego.

Matusiak K., 1964: Przewrót wojskowy w Cieszynie w roku 1918. W: Wspomnienia Cieszyniaków. Oprac. L. Brożek. Warszawa: Pax, s. 230-242.

Miękina L., 1991: Wspótcześni wobec etosu Stalmacha. W: P. Stalmach: Pamiętniki. Cieszyn [reprint], s. IV-X.

Nycz R., 2010: Możliwa historia literatury. „Teksty Drugie”, nr 5, s. 167-184.

Pamiętnik Czytelni Ludowej w Cieszynie na Szlasku austryackim wydany z powodu 25-letniego jej jubileuszu, 1887. Cieszyn: Czytelnia Ludowa.

Pilch J., 1974: Z dawnych dziejów książki polskiej na Śląsku Cieszyńskim. „Biuletyn Informacyjny Biblioteki Śląskiej”, t. 19, s. 41-44.

[Pindór J.], 1932: Pamiętnik ks. dr. Jana Pindóra. Oprac. O. Michejda. Cz. 1. Czeski Cieszyn: Towarzystwo Ewangelickie Oświaty Ludowej.

Sajko M., red., 1996: A-Z. Mała encyklopedia PWN. Warszawa: Wydawnictwo Naukowe PWN.

Sosna W., 1998: Poczciwy żywot ,kamizelkorza”. „Słowo i Myśl”, nr 3, s. 8-9.

Sosna W., 2015: Barwy luteranizmu na Ślasku Cieszyńskim. Wybór prac. Katowice: Polskie Towarzystwo Ewangelickie.

Spyra J., red., 2001: Książka, biblioteka, szkoła w kulturze Śląska Cieszyńskiego. Materiały z konferencji naukowej, Cieszyn 4-5 listopada 1999. Cieszyn: Książnica Cieszyńska.

Spyra J., 2015: Historiografia a tożsamość regionalna $w$ czasach nowożytnych na przykładzie Śląska Cieszyńskiego w okresie od XVI do początku XX wieku. Częstochowa: Wydawnictwo Akademii im. J. Długosza.

Stalmach P., 1910: Pamiętniki. W: E. Grim: Pawet Stalmach. Jego życie i działalność w świetle prawdy. Cieszyn: Dziedzictwo bł. Jana Sarkandra, s. 129-310.

Studnicki G., 2015: Śląsk Cieszyński. Obrazy przeszłości a tożsamość miejsc i ludzi. Katowice: Wydawnictwo Uniwersytetu Śląskiego.

Szacki J., 1997: O narodzie i nacjonalizmie. „Znak”, nr 3, s. 4-31.

Szczepański J., 2013: Od Autora. W: Idem: Korzeniami wrosłem w ziemię. Ustroń: Galeria na Gojach, s. 7-8.

Szkaradnik K., 2016: Sporny charakter Zaolzia w świetle „Dziennika” Józefa Pilcha oraz innych wybranych narracji autobiograficznych. „Studia Etnologiczne i Antropologiczne", t. 16, s. 55-69.

Szkaradnik K., red., 2017: Zmieszany zapach książek i jabtek. Wybór korespondencji Jana Wantuly z lat 1899-1953. Ustroń-Katowice: Galeria na Gojach, Wydawnictwo Uniwersytetu Śląskiego.

Wantuła J., 1918: Przemówienie w Ustroniu na wiecu ludowym w roku 1918. Kopia J. Brody, mps, Archiwum Muzeum Ustrońskiego, sygn. MU/A/159 (JB).

Wantuła J., 2003: Pamiętniki. Red. W. Sosna. Cieszyn: Macierz Ziemi Cieszyńskiej.

Zabawski W., 1934: Droga do ziemi obiecanej. Ruch narodowy na Śląsku Cieszyńskim i udział w nim ewangelików (1848-1920). Cieszyn: Księgarnia „Nowe Kresy”.

Żebrok J., 2001: Pamiętnik śląskiego nauczyciela. Oprac. J. Miękina-Pindur. Cieszyn: Macierz Ziemi Cieszyńskiej. 